\title{
A Role for TrkA during Maturation of Striatal and Basal Forebrain Cholinergic Neurons In Vivo
}

\author{
Anne M. Fagan, ${ }^{1}$ Melinda Garber, ${ }^{2}$ Mariano Barbacid, ${ }^{2}$ Inmaculada Silos-Santiago,, ${ }^{2}$ and David M. Holtzman' \\ ${ }^{1}$ Departments of Neurology, Molecular Biology, and Pharmacology, and the Center for the Study of Nervous System \\ Injury, Washington University School of Medicine, St. Louis, Missouri 63110, and 2Department of Molecular Oncology, \\ Bristol-Myers Squibb Pharmaceutical Research Institute, Princeton, New Jersey 08543
}

\begin{abstract}
Nerve growth factor (NGF), acting via the TrkA receptor, has been shown to regulate the survival and maturation of specific neurons of the peripheral nervous system. Furthermore, exogenous NGF has potent actions on TrkA-expressing cholinergic neurons of the basal forebrain (BFCNs) and striatum. However, initial analysis of mice lacking NGF or TrkA revealed that forebrain cholinergic neurons were present in these animals through the fourth postnatal week. Because of the potential effects of NGF/TrkA interactions on these developing neurons, we have analyzed quantitatively the striatal and basal forebrain cholinergic neurons in trkA knock-out mice. By postnatal day (P) $7 / 8$, forebrain cholinergic neurons are smaller in trkA $(-/-)$ mice than those in wild-type littermate controls. However, cholinergic neuron number and fiber density in the hippocampus, a
\end{abstract}

target region of $\mathrm{BFCNs,} \mathrm{are} \mathrm{grossly} \mathrm{intact.} \mathrm{Interestingly,} \mathrm{by}$ P20-P25 trkA knock-outs contain significantly fewer (20-36\%) and smaller cholinergic neurons in both the striatum and septal regions, as compared with controls. Cholinergic fiber density within the hippocampus also is depleted in knock-outs by the end of the second postnatal week. Contrary to some predictions, despite expression of p75 ${ }^{\mathrm{NTR}}$ in the absence of trkA in BFCNs of these knock-out mice, many cells, although smaller, are still alive at P25. Our data suggest that, in the absence of NGF/TrkA signaling, striatal cholinergic neurons and BFCNs do not mature fully and that BFCNs begin to atrophy and/or die surrounding the time of target innervation.

Key words: TrkA; nerve growth factor; neurotrophin; knockout; development; $p 75^{\text {NTR }}$
The neurotrophins are a family of neurotrophic factors, which include nerve growth factor (NGF), brain-derived neurotrophic factor (BDNF), neurotrophin-3 (NT-3), and neurotrophin 4/5 (NT-4/5) (for review, see Thoenen, 1991; Chao, 1992). All neurotrophins bind to the low-affinity receptor p $75^{\text {NTR }}$ (Chao et al., 1986; Radeke et al., 1987; Rodriguez-Tebar et al., 1990, 1992), the function of which remains controversial. Recently, however, p $75^{\text {NTR }}$ has been implicated in processes leading to cell death (Rabizadeh et al., 1993; Rabizadeh and Bredesen, 1994; Carter and Lewin, 1997). Neurotrophins also bind members of the Trk family of receptor tyrosine kinases (for review, see Barbacid, 1994), and these interactions have been shown to be key mediators of neurotrophin actions in the peripheral nervous system (PNS) (Snider, 1994). NGF binds the TrkA receptor (Kaplan et al., 1991; Klein et al., 1991; Meakin and Shooter, 1991), and several studies have shown that NGF/TrkA interactions are critical for the survival and maintenance of many dorsal root ganglion neurons and most, if not all, neurons in the sympathetic nervous system (Johnson and Gorin, 1980; Levi-Montalcini, 1987; Crowley et al., 1994; Smeyne et al., 1994; Silos-Santiago et al., 1995; Fagan et al., 1996). Although the role of NGF and TrkA in

Received May 8, 1997; revised July 30, 1997; accepted Aug. 5, 1997.

This research was supported in part by a grant from the McDonnell Center for Cellular and Molecular Neurobiology (A.M.F.) and a Paul Beeson PhysicianFaculty Scholar Award from American Federation for Aging Research (D.M.H.) We thank D. Xia for her excellent technical assistance and Drs. W. Snider, W. Mobley, and E. Johnson for helpful comments.

Correspondence should be addressed to Dr. Anne M. Fagan, Department of Neurology, Center for the Study of Nervous System Injury, Washington University School of Medicine, 660 South Euclid Avenue, Box 8111, St. Louis, MO 63110.

Copyright (C) 1997 Society for Neuroscience $0270-6474 / 97 / 177644-11 \$ 05.00 / 0$ the development of the PNS has been well defined now, their role in CNS development is less clear.

Two of the main populations of NGF-responsive CNS neurons that have been characterized extensively are the cholinergic neurons of the basal forebrain and striatum (Gnahn et al., 1983; Martinez et al., 1985; Mobley et al., 1985, 1986; Vantini et al., 1989; Longo et al., 1992). Basal forebrain cholinergic neurons (BFCNs) are projection neurons, the axons of which extend throughout the hippocampus and neocortex and are important for attention, learning, and memory functions (Coyle et al., 1983; Richardson and DeLong, 1988; Olton et al., 1991). Striatal cholinergic neurons are large interneurons involved in the control of movement (Schwarz et al., 1986). Studies have shown that both populations of neurons express TrkA (Holtzman et al., 1992, 1995; Steininger et al., 1993; Sobreviela et al., 1994; Li et al., 1995) and that NGF is expressed in the target regions of these cells (Large et al., 1986; Whittemore et al., 1986; Lu et al., 1989; Mobley et al., 1989). Furthermore, the expression levels of NGF are low at birth in the target of both populations and then increase substantially in the postnatal period (Large et al., 1986; Whittemore et al., 1986; Lu et al., 1989; Mobley et al., 1989), correlating with the maturation of both striatal cholinergic neurons and BFCNs. Evidence suggesting that endogenous NGF directly participates in BFCN development includes studies in which intracerebroventricular injections of NGF antibodies were shown to attenuate neurochemical maturation of BFCNs during development (Vantini et al., 1989; Li et al., 1995). These studies did not demonstrate the effects of these antibodies on striatal cholinergic neurons.

Another more direct way to determine the importance of endogenous NGF and TrkA in the development of forebrain 
cholinergic neurons is to assess the CNS of NGF and trkA knock-out mice. It was reported initially that cholinergic neurons were present in both lines of mice. BFCN projections to hippocampus and neocortex appeared qualitatively normal in NGF $(-/-)$ mice by the fourth postnatal week (Crowley et al., 1994) but were decreased at the same time in trkA-deficient mice (Smeyne et al., 1994). Abnormalities of striatal cholinergic neurons were not reported in either knock-out strain. Because of the marked effects of NGF/TrkA interactions in the developing PNS and their potential activities in the developing CNS, it seems both interesting and important to determine precisely whether endogenous NGF/TrkA signaling is essential for the normal development of striatal and basal forebrain cholinergic neurons. Because these neurons mature between the first and fourth postnatal weeks (Mobley et al., 1989), we analyzed the number, size, appearance, and axonal projection patterns of these cells from postnatal day (P) P7-P25 in trkA knock-out mice. Our findings suggest that TrkA signaling is required for the normal maturation and possibly the survival of both basal forebrain and striatal cholinergic neurons. In addition, they suggest that many neurons can survive for prolonged periods despite continued expression of p $75^{\text {NTR }}$ in the absence of trkA.

\section{MATERIALS AND METHODS}

Tissue. Mice homozygous for the trkA deletion [trkA $(-/-), n=10]$; $\operatorname{trkA}$ heterozygous $[\operatorname{trkA}(+/-), n=3]$; and wild-type $[\operatorname{trkA}(+/+), n=9]$ littermate controls were analyzed at P7/8 $(n=8)$ and P20-P25 $(n=14)$. All pups were generated from matings of trkA $(+/-)$ heterozygous mice. Before fixation, tail biopsies were taken for genotypic analysis as described (Smeyne et al., 1994). Animals were perfused transcardially with $0.1 \mathrm{M}$ PBS, followed by $4 \%$ paraformaldehyde in PBS. Brains were removed and post-fixed in this same fixative overnight at $4^{\circ} \mathrm{C}$ and then cryoprotected in $30 \%$ sucrose in PBS. Tissue sections were cut in the coronal plane at $40 \mu \mathrm{m}$ on a freezing sliding microtome, and adjacent series through the striatum, medial septal nucleus (MS), and hippocampus were processed for immunocytochemistry and/or histochemistry. Additional sets of animals at $\mathrm{P} 7$ [wild-type, $n=2 ; \operatorname{trk\mathrm {A}}(+/-), n=1$; and $\operatorname{trkA}(-/-), n=3]$ and P13 $[\operatorname{trkA}(+/-), n=2 ; \operatorname{trkA}(-/-), n=2]$ were perfused transcardially with PBS and frozen on dry ice. Coronal tissue sections through the septal region were cut at $20 \mu \mathrm{m}$ on a cryostat and processed with the terminal deoxynucleotidyl transferase (TdT)mediated dUTP-biotin nick end labeling (TUNEL) method to identify cells with fragmented DNA.

Histology. Free-floating tissue sections through the striatum and MS were processed for peroxidase immunocytochemistry (ICC), using antibodies to choline acetyltransferase (ChAT) (1:200, Chemicon, Temecula, CA) as described previously (Li et al., 1995) to visualize cholinergic neuronal cell bodies. Adjacent sections were processed for NADPHdiaphorase (NADPH-d) histochemistry, as described (Holtzman et al., 1994), to identify noncholinergic, nitric oxide synthase (NOS)-containing neurons of the striatum. Cholinergic fibers in the hippocampus were visualized with an antibody to p75 NTR (REX, 1:2000, gift of G. Weskamp and L. Reichardt, University of California San Francisco) (Weskamp and Reichardt, 1991), as well as with acetylcholinesterase (AChE) histochemistry, as described (Fagan et al., 1997). Cryostat sections through the septal region of P7 and P13 animals were stained with the TUNEL method (fluorescent Apoptag Plus kit, Oncor, Gaithersburg, MD) to identify fragmented DNA characteristic of apoptotic nuclei. TUNEL-positive nuclei were identified by FITC fluorescence. Tissue from knock-out and control animals of each age was processed identically and simultaneously for each of the histological stains to permit comparison among animals of different genotypes and ages. In addition, staining was performed multiple times to assess reliability.

Quantitative analysis. The striatum (defined as the area of striatal tissue dorsal to the anterior commissure and extending from its incipience rostrally to the end of the fornix caudally) and the medial septum were analyzed in their entirety. Every other section (for P7/8) or every third section (for P20-P25) through these structures was processed for ChAT ICC (as well as NADPH-d histochemistry for P20-P25 animals) and visualized with a Nikon FXL microscope linked to a computer via a
Dage CCD-72 camera. ChAT-immunoreactive (ChAT-IR) and NADPH-d-positive cell numbers were counted in an unbiased manner as described previously (Holtzman et al., 1996), using the optical dissector method (Gundersen, 1986; West, 1993) in combination with the Cavalieri method for estimating reference volume (Cavalieri, 1966). A total of 7-10 sections per structure was analyzed. Cells were sampled with a dissector frame taped to the monitor screen. Cells were counted if they contained a nucleus that fell within the dissector frame under a $100 \times$ objective. The cross-sectional area of counted cellular profiles also was measured with the National Institutes of Health Image analysis system (version 1.57), as previously described (Holtzman et al., 1996). All quantification was done blind to animal genotype. Between-group (i.e., genotype) analysis of mean neuron number and mean cross-sectional neuronal profile area of age-matched samples was performed by Student's $t$ test. Statistical significance was defined as $p<0.05$.

Quantification of TUNEL-positive nuclei in the medial septum was performed on an additional set of P7 and P13 animals. The total number of fluorescent profiles in the septal region in four representative, equally spaced sections from each animal was obtained manually with a $40 \times$ objective, and comparisons were made between groups by Student's $t$ test. Statistical significance was defined as $p<0.05$.

\section{RESULTS}

\section{TrkA is required for the normal maturation of striatal cholinergic neurons during development}

To investigate whether TrkA signaling is required for the normal maturation of striatal cholinergic neurons, we analyzed ChATimmunostained tissue sections from postnatal trkA $(-/-)$ animals and wild-type littermate controls. Phenotypic changes in striatal cholinergic neurons were observed in knock-out animals by P7/8. Qualitatively, many neurons appeared smaller in knock-outs, and ChAT immunoreactivity was often less intense (Fig. 1A,B), suggesting that less ChAT protein was present in the absence of trkA. To quantitate neuronal changes, we counted in an unbiased manner the total number of ChAT-IR cells in the striatum at P7/8 [wild-type, $n=4$; trkA $(-/-), n=4$ ] via the optical dissector method (Gundersen, 1986; West, 1993) in combination with the Cavalieri method for estimating reference volume (Cavalieri, 1966). Although the mean number of striatal ChAT-IR neurons in knock-out and control animals was not significantly different at P7/8 (Fig. 2A), the mean cross-sectional area of cholinergic neuronal profiles in the knock-out striatum was significantly less (10-20\%) than controls (Fig. 2B).

Analysis of the striatum from animals at P20-P25 [wild-type, $n=5$; trkA $(-/-), n=6]$ revealed additional defects in knock-out animals. The cholinergic neuronal atrophy observed in the trkA $(-/-)$ striatum at $\mathrm{P} 7 / 8$ was still apparent at $\mathrm{P} 20-\mathrm{P} 25$ (Figs. $1 C, D$, $2 B)$. In addition, knock-outs exhibited fewer numbers $(20 \%)$ of ChAT-IR cells than controls at this later time point, although the difference in neuron number did not quite reach statistical significance $(p=0.059)$ (Fig. $2 A)$. It was also of note that the absolute number of detectable ChAT-IR neurons was greater in both wild-type and knock-out animals at P20-P25, as compared with $\mathrm{P} 7 / 8$. This is likely to be attributable in part to the increase in ChAT expression that occurs between these ages (Mobley et al., 1989) (discussed below). The observed defect in the number of detectable striatal cholinergic neurons in knock-out animals at P20-P25 cannot be attributed to smaller brain size because, despite the fact that postnatal trkA $(-/-)$ mice that survive to this age are typically smaller (in body and total brain weight) than their wild-type littermates (Smeyne et al., 1994), striatal volume did not differ between the groups at either time point [wildtype $=1.83 \mathrm{~mm}^{3} \pm 0.15 ; \operatorname{trkA}(-/-)=1.73 \mathrm{~mm}^{3} \pm 0.14, p>$ $0.05]$. Interestingly, striatal cholinergic neurons in trkA $(+/-)$ heterozygotes appeared normal at P22 and P25 and did not differ 


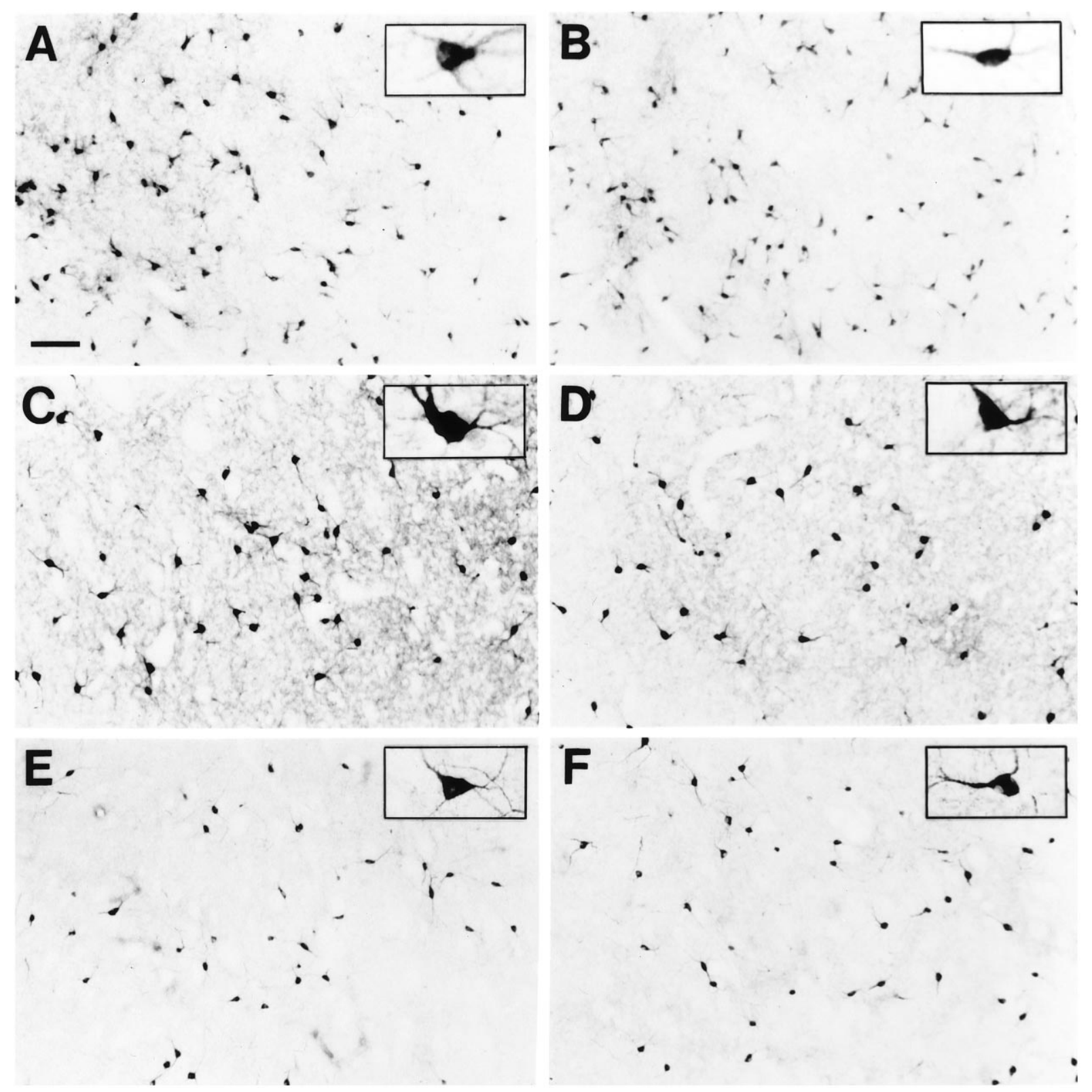

Figure 1. Striatal neurons of wild-type and trkA (-/-) mice stained with antibodies to ChAT or NADPH-d histochemistry. $A$, ChAT immunoreactivity identifies cholinergic neurons in the striatum of wild-type mice at P7. B, trkA (-/-) mice exhibit ChAT-positive cells in the striatum at P7, but many cells are smaller (see insets in $A$ and $B$ ), and immunolabeling intensity in both cell bodies and neuropil is generally less than that observed in wild-type mice of the same age. $C$, By P22, cholinergic neurons in the wild-type striatum are large and stain darkly with antibodies to ChAT. A plexus of immunoreactive fibers also can be observed throughout the striatal neuropil. $D$, ChAT-positive cells in the trkA (-/-) striatum at P22 are smaller (inset in $D$ ) than those in wild-type animals (inset in $C$ ) and often exhibit reduced ChAT immunoreactivity. Cholinergic fiber staining in the striatal neuropil also is reduced in knock-outs at this age. $E$, Noncholinergic neurons of the striatum, which stain for NADPH-d, are observed throughout the wild-type striatum at P22. F, Neurons stained for NADPH-d in P22 trkA (-/-) mice appear indistinguishable in size and staining intensity from those of wild-type animals. Scale bar in $A, 100 \mu \mathrm{m}$.

in cell size from wild-type littermate controls [wild-type $=204.35$ $\left.\mu \mathrm{m}^{2} \pm 8.17 ; \operatorname{trkA}(+/-)=194.35 \mu \mathrm{m}^{2} \pm 13.13 ; p>0.05\right]$.

To assess whether the phenotypic differences observed in the striatum were specific for the cholinergic system or merely reflected generalized neuronal death and/or atrophy in trkAdeficient animals, we also analyzed a noncholinergic population of neurons in the striatum. Noncholinergic striatal neurons that contain nitric oxide synthase (NOS) do not express TrkA and can be visualized with a histochemical stain for NADPH-d (Holtzman et al., 1994). In contrast to the differences observed in cholinergic striatal neurons by $\mathrm{P} 20-\mathrm{P} 25$, we found no difference between groups in the number or size of NADPH-d-positive cells of the striatum (Figs. $1 E, F, 2 A, B$ ). Together, these results suggest that TrkA signaling is specifically required for the normal maturation of cholinergic neurons in the striatum.

\section{TrkA is required for the normal maturation of basal forebrain cholinergic neurons during development}

We observed phenotypic defects in developing basal forebrain cholinergic neurons of trkA knock-out mice that were similar in 


\section{Striatum}

A

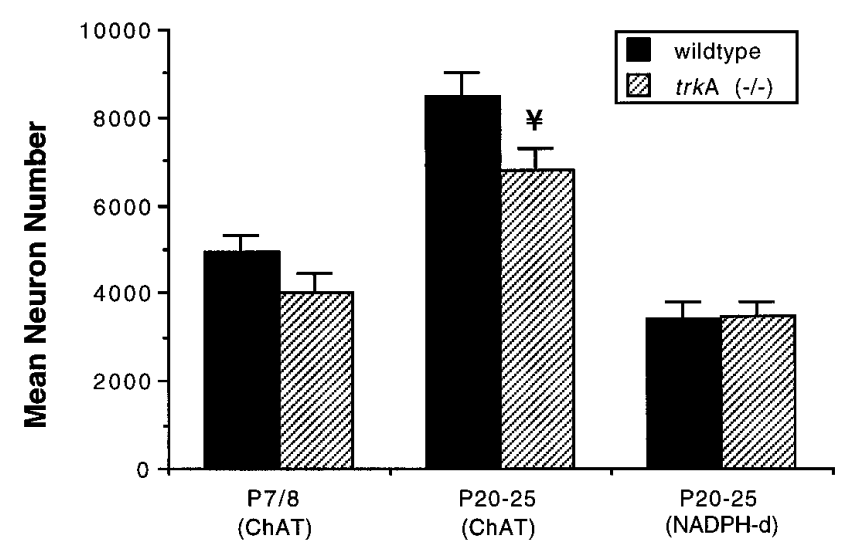

B

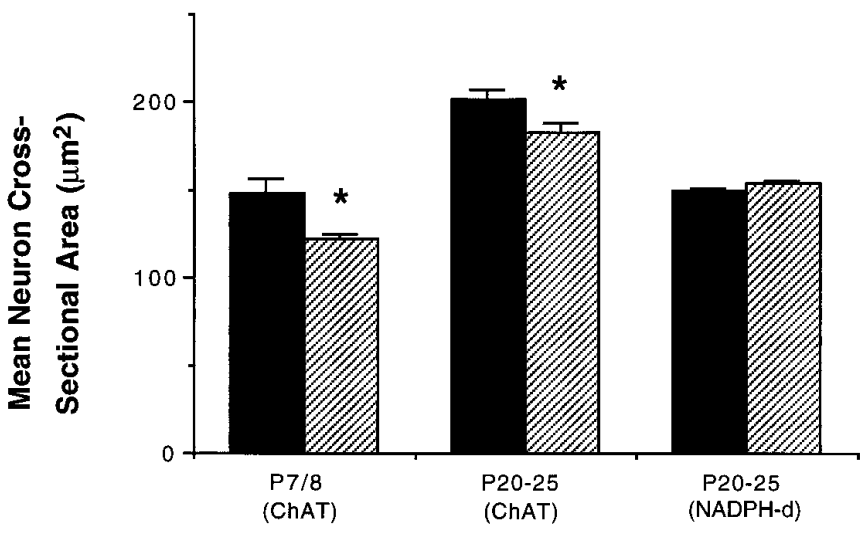

Figure 2. Quantitative analysis of the number and size of neurons in the striatum of wild-type and trkA (-/-) mice during development. $A$, Unbiased counting methods were used to determine the total number of striatal neurons stained with antibodies to choline acetyltransferase $(C h A T)$ and NADPH-diaphorase (NADPH- $d$ ) at P7/8 and P20-P25. Although the mean number of ChAT-positive cells in wild-type $(n=4)$ and trkA knock-out $(n=4)$ mice was not different at P7/8, trkA $(-/-)$ mice $(n=6)$ at P20-P25 exhibited fewer ChAT-immunoreactive neurons than wild-type controls $(n=5$; $¥, p=0.059)$. The number of striatal neurons stained for NADPH-d did not differ between the groups at P20-P25. B, The mean cross-sectional area of striatal profiles stained for ChAT and NADPH-d was determined. ChAT-immunoreactive neuronal profiles in the striatum of trkA $(-/-)$ mice were significantly smaller than those of wild-type animals at P7/8 and P20-P25. However, cells stained for NADPH-d were of similar size in the two groups of animals at P20-P25. Asterisk indicates statistical significance, $p<0.05$. Error bars, SEM.

many ways to those seen in the striatum. As observed in the striatum, the intensity of ChAT immunoreactivity in septal neurons and their fibers in knock-out animals often appeared qualitatively lighter than in wild-type cells (Fig. 3). Also, although cholinergic neuron number in the medial septum was not different between knock-outs and controls at $\mathrm{P} 7 / 8$ (Fig. 4A), knock-out neurons were significantly smaller than those in wild-type animals at this early time point (Figs. $3 A, B, 4 B$ ). By P20-P25, trkA (-/-) animals exhibited significantly fewer $(36 \%)$ numbers of ChAT-IR cells in the medial septum than control animals (Fig. 4A), and those neurons remaining were atrophic (Figs. $3 C, D, 4 B$ ). Qualitatively, atrophic changes observed in the medial septal region also were noted in cholinergic neurons in the vertical and horizontal limbs of the diagonal band and in the nucleus basalis (data not shown). Cholinergic cell size in the medial septum of trkA $(+/-)$ heterozygotes at P22 and P25 was not different from wild-type controls [wild-type $=179.94 \mu \mathrm{m}^{2} \pm 11.13$; trkA $(+/-)$ $\left.=186.40 \mu \mathrm{m}^{2} \pm 13.5, p>0.05\right]$.

Two possibilities exist to explain the differences in striatal and septal cholinergic neuron number observed between wild-type and trkA knock-out animals at P20-P25. First, it must be noted that both wild-type and knock-out animals have greater numbers of detectable ChAT-positive cells at P20-P25, as compared with $\mathrm{P} 7 / 8$. The fact that there are fewer ChAT-immunoreactive neurons in trkA $(-/-)$ animals at $\mathrm{P} 20-\mathrm{P} 25$, as compared with controls at this age, could reflect the lack of the normal developmental increase in ChAT expression, which occurs in these cells between P7 and P25 (Mobley et al., 1989). Thus, if there is less of an increase in ChAT protein in trkA knock-outs, fewer cells are detected by the ICC method and counted. A second, but not mutually exclusive, possibility is that there is an increase in developmental cell death taking place in trkA (-/-) animals before P20-P25. To address the question of cell death, we processed a sampling of sections through the septal region of P7 and P13 knock-out and control animals with the TUNEL method to identify nuclear fragmented DNA indicative of apoptosis. Whereas very few TUNEL-positive nuclei were detected in the septum of either knock-out or control mice at P13, trkA (-/-) animals exhibited a significantly greater number of TUNELpositive nuclei at P7 than was observed in controls (Fig. 5). The time-dependent pattern of TUNEL labeling observed in control animals suggests that most naturally occurring cell death in this region takes place before $\mathrm{P} 13$, in agreement with a recent report (Van der Zee et al., 1996). Although we cannot be certain that TUNEL labeling was present specifically in cholinergic neurons, these results also suggest that, in addition to decreased ChAT expression in knock-out neurons, developmental cell death in the septal region is exacerbated in trkA-deficient animals.

\section{TrkA is required for development of the mature pattern of cholinergic innervation of the hippocampus}

Our observation of a defect in the number and size of septal cholinergic neurons in knock-out animals at P20-P25, together with a greater number of TUNEL-positive nuclei in this same region at an earlier time point, suggests that TrkA signaling is required for the normal maturation and possibly the survival of this NGF-sensitive neuronal population. Because the neurotrophic hypothesis posits that trophic factor-dependent neurons obtain trophic support from their target regions during development (for review, see Thoenen, 1991), we assessed the timing and extent of cholinergic fiber innervation of the hippocampus, the target region of septal cholinergic neurons. Sections through the hippocampus of trkA knock-out and control animals were stained with antibodies to $\mathrm{p} 75^{\mathrm{NTR}}$ as well as with AChE histochemistry to identify cholinergic fibers. p75 ${ }^{\text {NTR }}$-IR colocalizes with ChAT-IR in BFCNs (Hefti et al., 1986; Batchelor et al., 1989) and in our experience proves to be better for visualizing basal forebrain cholinergic fibers than does the cytosolic ChAT marker. Similar to what has been shown in rats (Milner et al., 1983), we observed cholinergic ( $\left.\mathrm{p} 75^{\mathrm{NTR}}-\mathrm{IR}\right)$ fibers within the stratum oriens and stratum radiatum of the wild-type hippocampus at P7/8 (Fig. 6). Individual fibers also could be discerned in the molecular layer of the dentate gyrus at this time (Fig. 6G). Interestingly, we observed a similar pattern of $\mathrm{p} 75^{\mathrm{NTR}}$-IR in the 

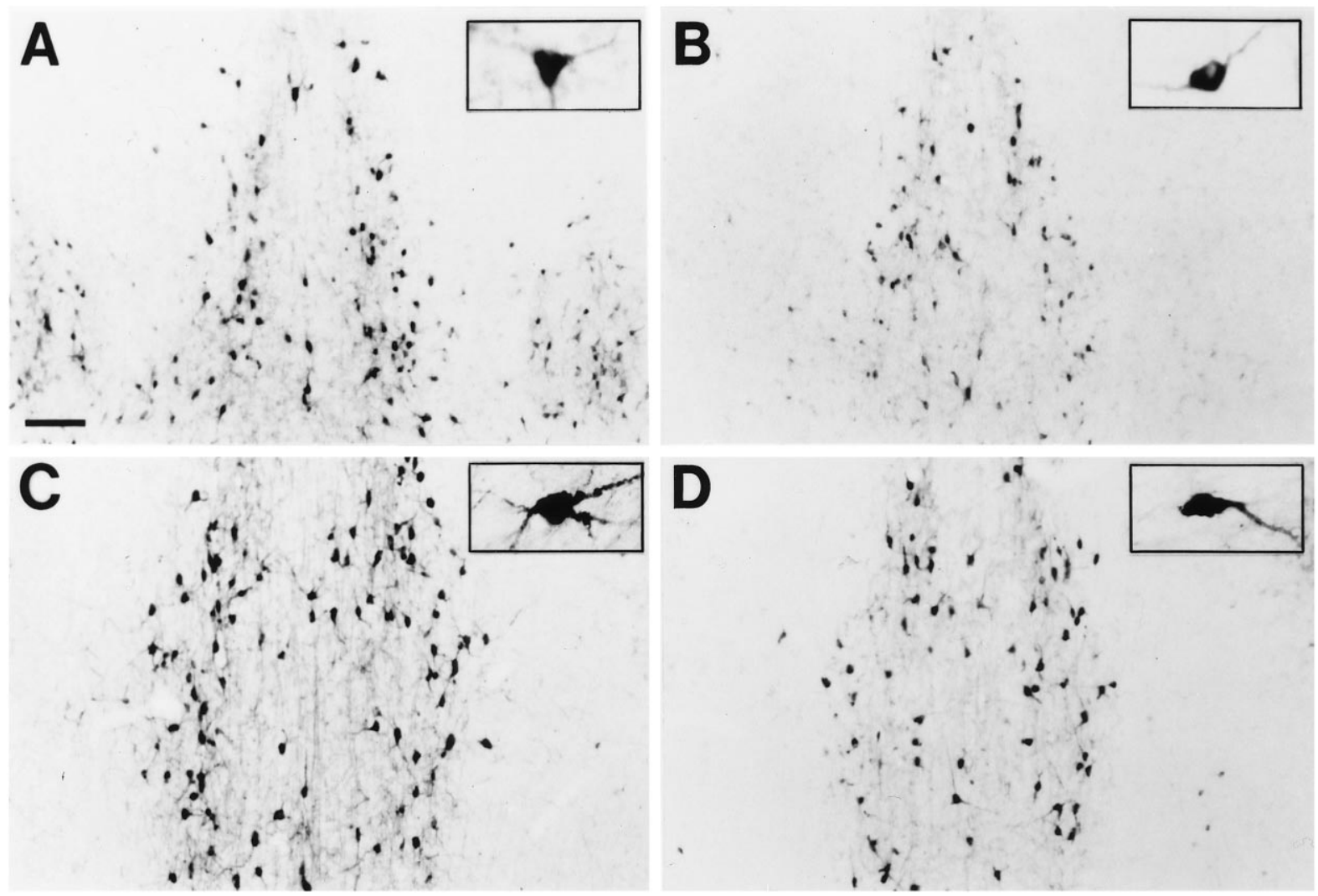

Figure 3. Neurons in the medial septum of P7 and P22 wild-type and trkA (-/-) mice stained with antibodies to ChAT. A, ChAT-immunoreactive neurons in the medial septum of P7 wild-type mice appear larger (compare insets in $A$ and $B$ ) and stain more darkly with the ChAT antibody than those in trkA $(-/-)$ mice $(B)$ of the same age. By P22, the difference in medial septal cell size and ChAT immunostaining intensity between wild-type $(C)$ and trkA knock-out $(D)$ mice is even clearer than at the earlier time point. ChAT-immunoreactive processes also appear more complex in the wild-type, as compared with the knock-out mice (see insets in $C$ and $D$ ). In addition, there appear to be reduced numbers of ChAT-positive neurons in the medial septum of knock-out animals at this age. Scale bar in $A, 100 \mu \mathrm{m}$.

hippocampus of trkA (-/-) animals at P7/8 (Fig. 6). Although the level of innervation of the dentate molecular layer varied among individual knock-out animals, it was generally similar to that seen in wild-type controls.

By P20-P25, however, trkA-deficient animals exhibited a profound defect in cholinergic fiber density in all regions of the hippocampus (Fig. 7), coincident with the observed atrophy and apparent loss of cholinergic neurons in the medial septum by this time. Similar changes also were noted in the cortex, reflecting abnormalities in the cholinergic neurons of the nucleus basalis. This defect in cholinergic fiber density in trkA (-/ ) animals was observed as early as P14 and was seen in sections stained with p $75^{\text {NTR }}$ antibodies and by AChE histochemistry (data not shown).

Most, if not all, medial septal cholinergic neurons express p75 ${ }^{\text {NTR }}$ (Hefti et al., 1986; Batchelor et al., 1989). Interestingly, although there was a marked decrease in $\mathrm{p} 75^{\mathrm{NTR}}$-positive fiber staining in the hippocampus of trkA-null mice after the second postnatal week, cell bodies of surviving medial septal cholinergic neurons continued to express p75 ${ }^{\text {NTR }}$ (Fig. 7, insets $A$ and $B$ ). Thus the paucity of hippocampal fiber staining in these animals is unlikely to be attributable simply to downregulation of p $75^{\text {NTR }}$ within knock-out neurons. It could reflect, however, an abnormality in the transport of $\mathrm{p} 75^{\mathrm{NTR}}$ to the axonal regions in knock-out animals or perhaps indicate an actual loss of axons by this time in the absence of trkA. In support of this latter hypothesis, silver staining (Gallyas et al., 1980) in a preliminary experiment re- vealed argyrophilia in regions known to contain septal cholinergic afferents in a P16 knock-out animal, indicating the presence of degeneration products (data not shown). This may indicate a dying back of axons at this time. In the same experiment argyrophilia was not observed in the wild-type hippocampus or in knock-out animals at P7 or P22. Together, these findings indicate that BFCNs can extend axons early in development to innervate their target region in the absence of TrkA signaling but require TrkA for their normal maturation and possibly their continued survival.

\section{DISCUSSION}

Analysis of mice lacking one of the neurotrophins (Crowley et al., 1994; Ernfors et al., 1994; Farinas et al., 1994; Jones et al., 1994; Conover et al., 1995; Liu et al., 1995) or their signaling Trk receptors (Klein et al., 1993, 1994; Smeyne et al., 1994; Fagan et al., 1996) has confirmed that certain PNS neurons require neurotrophin signaling for their survival in vivo. Recently, it has been shown that certain CNS neurons require TrkB signaling for survival during development (Minichiello and Klein, 1996; Alcantara et al., 1997). What remains to be determined is whether the survival and/or maturation of developing trkA-expressing CNS neurons is similarly governed by trophic interactions. The present results are the first to show that certain CNS neurons require TrkA signaling during their normal maturation in vivo. Quantitative analysis of developing trkA (-/-) mice demonstrated that trkA is required during the normal maturation of 
Medial Septum

A

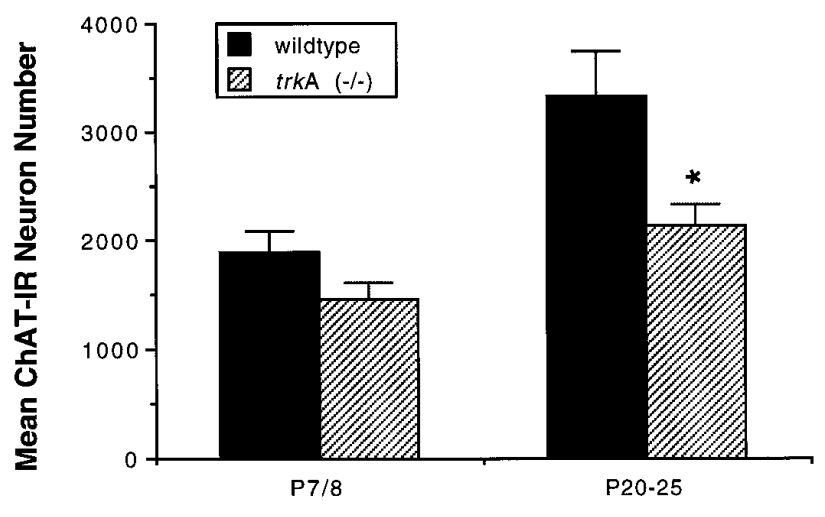

B

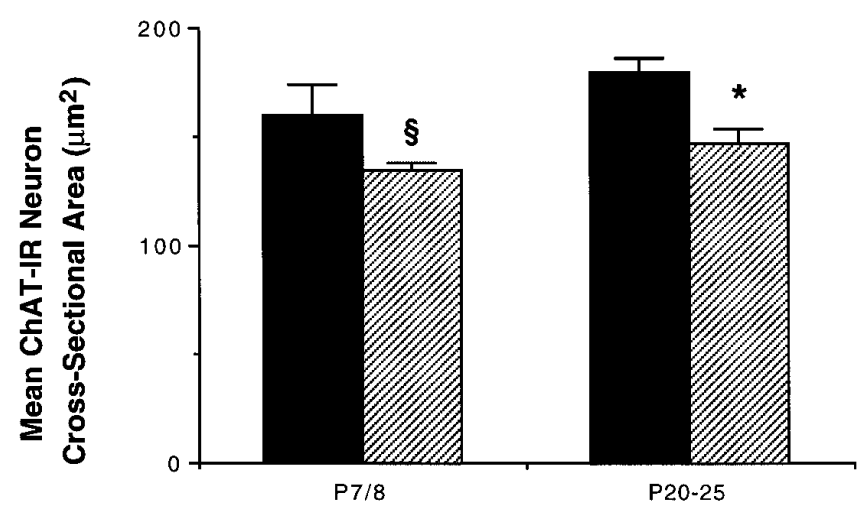

Figure 4. Quantitative analysis of the number and size of cholinergic neurons in the medial septum of wild-type and trkA $(-/-)$ mice during development. $A$, Unbiased counting methods were used to determine the total number of septal neurons stained with antibodies to ChAT at P7/8 and P20-P25. Although the mean number of ChAT-positive cells in wild-type $(n=4)$ and trkA knock-out $(n=4)$ mice was not different at $\mathrm{P} 7 / 8$, trkA $(-/-)$ mice $(n=6)$ at P20-P25 exhibited significantly fewer immunoreactive neurons than wild-type controls $(n=5)$. $B$, The mean cross-sectional area of ChAT-positive profiles in the medial septum of trkA knock-out mice and wild-type controls was determined. At P7, ChAT-positive neuronal profiles in knock-out animals were smaller than those in wild-type mice ( $\$, p=0.053)$. By P20-P25, immunoreactive cells in the knock-out septum were significantly atrophic, as compared with wild-type controls. Asterisk indicates statistical significance, $p<0.05$. Error bars, SEM.

projecting $\mathrm{BFCN}$ and cholinergic interneurons of the striatum. Although there were abnormalities in cell size and ChAT staining intensity by $\mathrm{P} 7 / 8$ in both cholinergic populations, neuron number was relatively unaffected, and BFCN axons had reached most of their targets in the hippocampus. In contrast, significant changes in cholinergic neuron number, as well as $\mathrm{BFCN}$ projections, were apparent by $\mathrm{P} 20-\mathrm{P} 25$. The greater number of TUNEL-positive cells in the septum of knock-outs at P7 suggests that some of the decrease in BFCN cell number observed at later time points may be attributable to cell death, not merely to downregulation of ChAT within knock-out neurons. Interestingly, BFCNs that remained alive in knock-out animals at P25 still expressed p75 ${ }^{\text {NTR }}$, suggesting that $\mathrm{p} 75^{\mathrm{NTR}}$ expression during a $25 \mathrm{~d}$ postnatal period

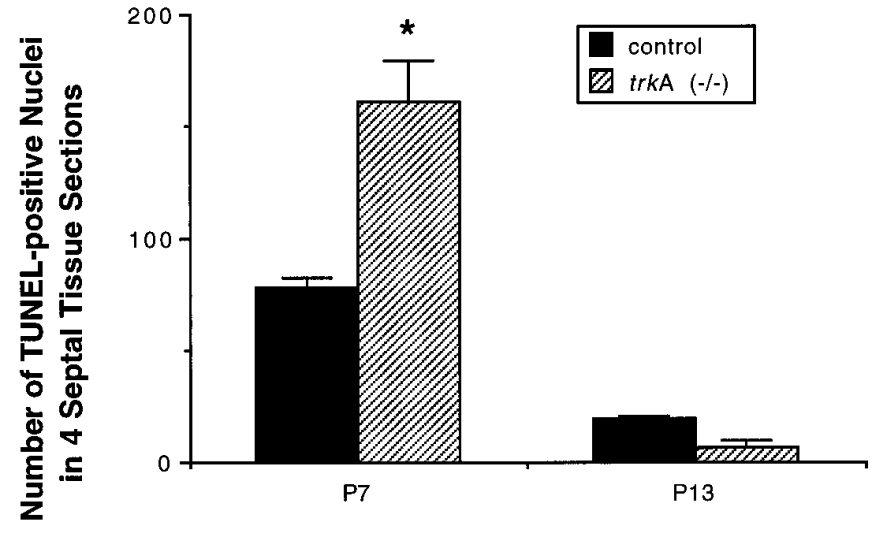

Figure 5. Counts of TUNEL-positive profiles in four tissue sections through the septal region of trkA $(-/-)$ mice and littermate controls. TrkA (-/-) mice exhibited significantly greater numbers of TUNELpositive nuclei in the septal region at $\mathrm{P} 7$ than were observed in littermate controls. This indicates that at this time point there is likely to be an increase over baseline in the amount of naturally occurring cell death in trkA knock-out animals. By P13, both groups of mice displayed few TUNEL-stained profiles in the septal region. Asterisk indicates statistical significance, $p<0.05$. Error bars, SEM.

can occur in non-trkA expressing neurons exposed to NGF, without massive cell death ensuing.

\section{Role of TrkA in cholinergic neuronal maturation and/or survival in the developing CNS}

Our observation of cholinergic neuronal atrophy and lighter ChAT immunostaining in the striatum and basal forebrain of trkA knock-outs by $\mathrm{P} 7$ suggests that these $\mathrm{CNS}$ neurons require trkA even for some aspects of their normal early maturation during development. These defects likely result from the absence of NGF signaling via TrkA, because cell size and ChAT expression can be regulated by NGF in these developing systems (Gnahn et al., 1983; Mobley et al., 1985, 1986; Vantini et al., 1989; Longo et al., 1992).

What remains unclear is the extent to which TrkA is required for neuronal survival later during development. NGF has been shown to stimulate ChAT expression, but not neuronal survival, in BFCNs in culture (Friedman et al., 1993). Our observations of fewer ChAT-IR neurons in striatum and basal forebrain in knock-outs by P20-P25, as well as a greater number of TUNELlabeled cells in the septum at P7, support the argument that TrkA signaling plays some role in neuronal survival in vivo. It should be noted that, whereas some TUNEL labeling in trkA $(-/-)$ mice is likely to be localized to cholinergic neurons, it is possible that many TUNEL-positive cells are noncholinergic. Loss of BFCNs in developing trkA (-/-) mice would be consistent with observations of BFCN cell death on depletion of target-derived trophic support between the first and fourth postnatal weeks (Burke et al., 1994a,b; Cooper et al., 1996). It is during this time (P7-P21) that NGF levels in the target of BFCNs as well as the striatum are increasing (Large et al., 1986; Whittemore et al., 1986; Lu et al., 1989; Mobley et al., 1989). Thus NGF, whether derived from local sources (Lu et al., 1989; Lauterborn et al., 1995) or from the target region, likely regulates these cholinergic systems by activating TrkA. That decreased cell size and ChAT immunolabeling intensity precede differences in neuron number may reflect differences in our methodological ability to discern these changes or may indicate an actual change in neurotrophin function during development. For example, cell size and ChAT levels may be 


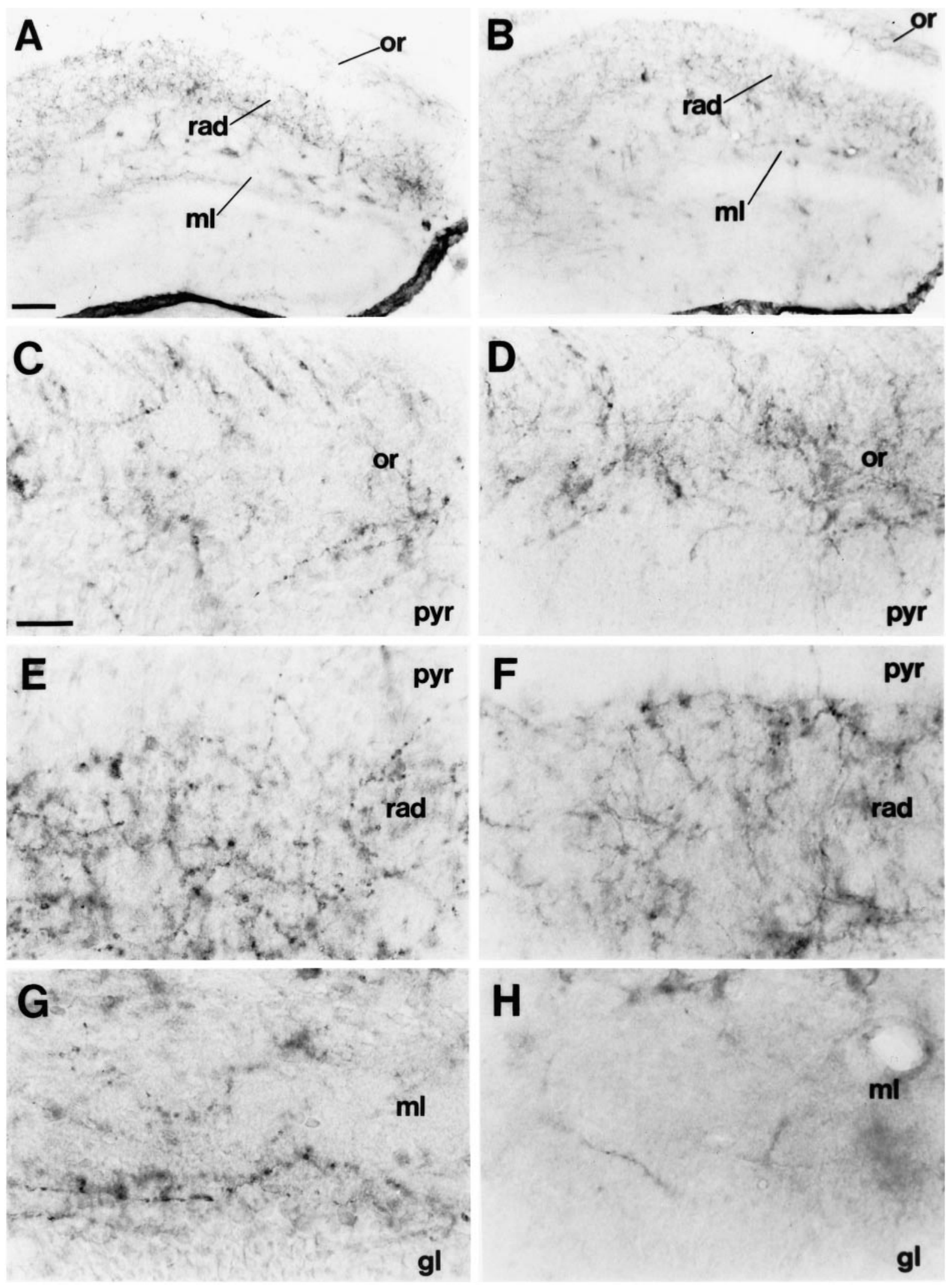

Figure 6. Immunoreactivity for $\mathrm{p} 75^{\mathrm{NTR}}$ in the hippocampus of wild-type and trkA (-/-) mice at P7. $A$, p75 ${ }^{\mathrm{NTR}}$-immunoreactive fibers are observed in the hippocampus of wild-type mice at P7. $B$, A similar pattern of fiber staining is observed in trkA knock-outs at this time. At higher magnification, individual fibers can be seen in many regions of the wild-type $(C, E, G)$ and trkA $(-/-)(D, F, H)$ hippocampus, including the stratum oriens $(C, D)$, stratum radiatum $(E, F)$, and molecular layer of the dentate gyrus $(G, H)$. Fiber density in these regions is not markedly different in the two groups of animals at this time. $g l$, Granular layer; $m l$, molecular layer; or, stratum oriens; $p y r$, pyramidal layer; $r a d$, stratum radiatum. Scale bars: in $A$, $B$, $100 \mu$ m; in $C-H, 20 \mu \mathrm{m}$. 


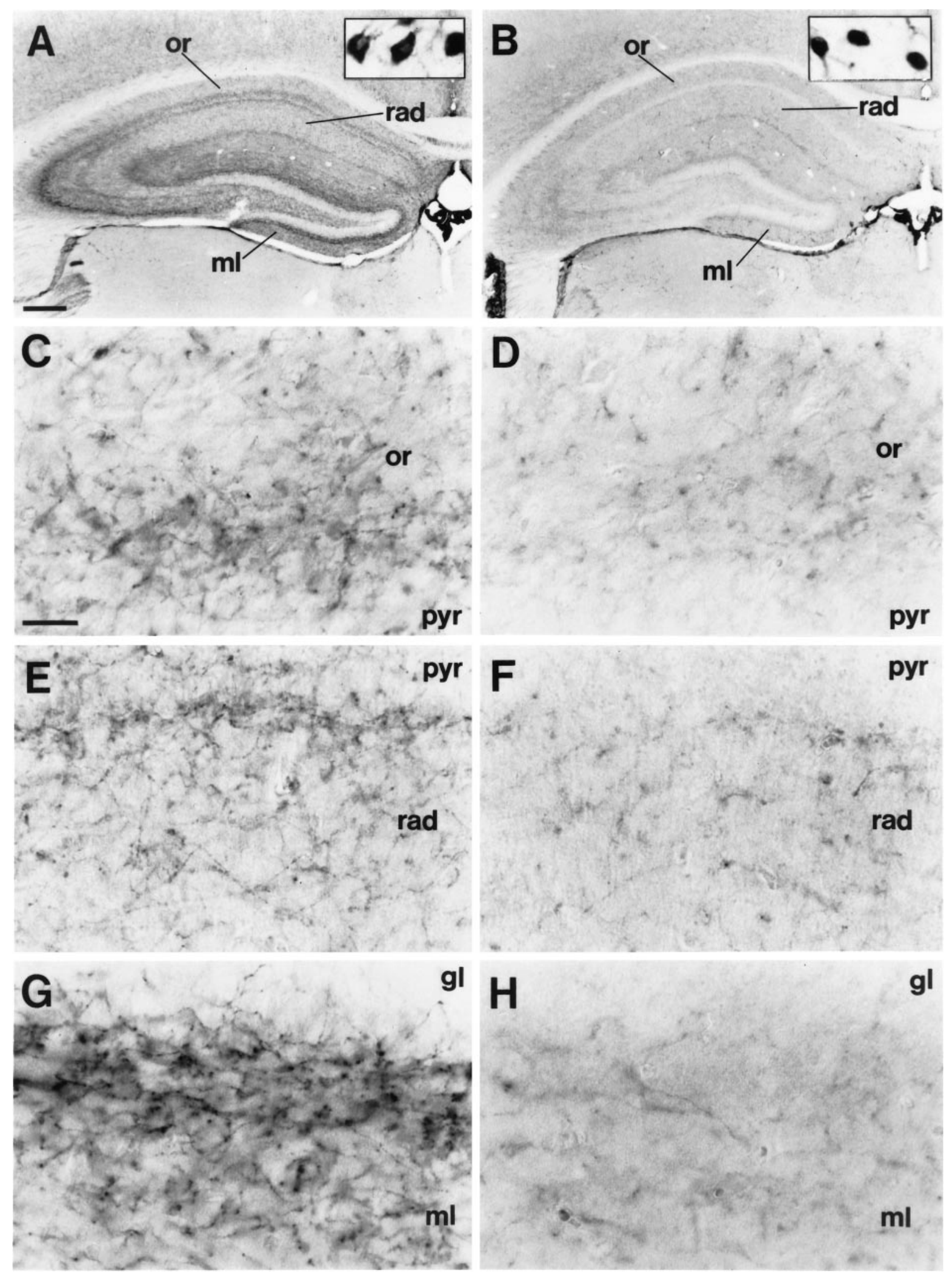

Figure 7. Immunoreactivity for $\mathrm{p} 75^{\mathrm{NTR}}$ in the hippocampus of wild-type and trkA (-/-) mice at P25. A, The adult laminated pattern of cholinergic

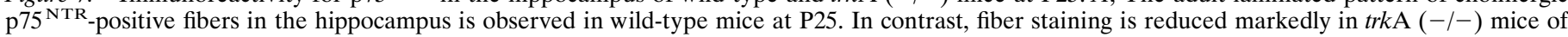
the same age $(B)$. Differences in fiber staining are observed in all regions of the hippocampus, including the stratum oriens $(C, D)$, stratum radiatum $(E$, $F)$, and molecular layer of the dentate gyrus $(G, H)$. Loss of fiber staining in the trkA knock-out mice $(B, D, F, H)$ likely does not merely reflect a simple downregulation of $\mathrm{p} 75^{\mathrm{NTR}}$ protein expression because the cell bodies of these projecting neurons in the medial septum, although clearly atrophic at this time (compare insets in $A$ and $B$ ), stain darkly with antibodies to $\mathrm{p} 75^{\mathrm{NTR}}$. $g l$, Granular layer; $m l$, molecular layer; or, stratum oriens; $p y r$, pyramidal layer; $\mathrm{rad}$, stratum radiatum. Scale bars: in $A, B, 100 \mu \mathrm{m}$; in $C-H, 20 \mu \mathrm{m}$. 
regulated by local NGF interactions early in development, whereas NGF may exert survival-promoting effects at later stages (e.g., once targets have been reached).

Interestingly, $60-80 \%$ of identified cholinergic neurons were still present in trkA knock-outs at P25. This contrasts markedly with the PNS, in which there is death over several days in sensory and sympathetic neurons in the absence of NGF or trkA (Crowley et al., 1994; Smeyne et al., 1994). It is noteworthy that striatal and basal forebrain cholinergic neurons are born prenatally and then mature over a 4-6 week period postnatally. One might speculate that, given the prolonged period over which these cells normally mature, all cholinergic neurons would die in older trkA knockouts. Unfortunately, the short lifespan of trkA $(-/-)$ mice precludes testing this hypothesis. It is also possible that, although TrkA is required for certain aspects of neuronal development (e.g., increase in cell size and ChAT expression), the majority of cholinergic neurons can survive in its absence. Another alternate, but not mutually exclusive, scenario is that cholinergic neuronal survival, either in wild-type or trkA knock-outs, also may be mediated via other trophic factor(s), such as fibroblast growth factor-2 (FGF-2), BDNF, NT-3, or ciliary neurotrophic factor (CNTF), all known to have trophic effects on BFCNs (Anderson et al., 1988; Otto et al., 1989; Alderson et al., 1990; Knüsel et al., 1991; Hagg et al., 1992; Koliatsos et al., 1994).

\section{Role of TrkA in cholinergic process outgrowth and target innervation during development}

TrkA (-/-) mice at P20-P25 displayed a profound deficit in cholinergic fiber density in the hippocampus, a defect first apparent in the second postnatal week. This paucity of fibers does not reflect a problem in axon guidance in the absence of TrkA, because knock-outs and controls exhibit a similar pattern of p75 ${ }^{\text {NTR }}$-IR fibers in the hippocampus at P7. Despite the fact that the level of $\mathrm{p} 75^{\mathrm{NTR}}$ can be regulated by NGF (Cavicchioli et al., 1989; Higgins et al., 1989), it is unlikely that an absence of detectable fibers in older knock-outs simply reflects downregulation of $\mathrm{p} 75^{\mathrm{NTR}}$, because the cell bodies of BFCNs in these same animals still exhibited staining for this marker (see inset, Fig. 7B). However, we cannot rule out completely a possible abnormality in axonal transport of $\mathrm{p} 75^{\mathrm{NTR}}$ in knock-outs.

Tissue sections stained for AChE, a marker for which the staining intensity in vivo is not regulated by exogenous NGF (Saffran et al., 1989; Hagg et al., 1990; Holtzman and Lowenstein, 1995), revealed the same defect in hippocampal fiber density (data not shown), suggesting an absence of fibers in the hippocampus of trkA knock-outs by the second postnatal week. The absence of staining could indicate a defect in axon arborization within target regions in the absence of TrkA. Data demonstrating hyperinnervation in tissues overexpressing NGF (Edwards et al., 1989; Albers et al., 1994; Davis et al., 1994) are consistent with this idea. However, our observation that cholinergic fiber density in the knock-out hippocampus at P20-P25 appeared less than what was observed initially in knock-out animals at P7 argues for more than a defect in arborization. There may be an actual loss of fibers with age. Such fiber loss would be expected if BFCNs are dying or even perhaps dysfunctional.

\section{Is the cholinergic phenotype in trkA (-I-) mice attributable to an absence of NGF signaling?}

Our data demonstrating impaired development of striatal and basal forebrain cholinergic neurons in trkA knock-out mice are consistent with the known trophic effects of NGF on these neu- rons (for review, see Gage et al., 1991; Longo et al., 1992) and are the first to show that striatal cholinergic interneurons require endogenous TrkA signaling for their normal maturation. It is noteworthy, however, that NGF and trkA knock-outs differ in their hippocampal cholinergic phenotype. Whereas cholinergic fiber staining is markedly abnormal in the hippocampus of P20P25 trkA (-/-) mice, it is present and qualitatively normal in NGF knock-outs of the same age (Crowley et al., 1994). Whether developing NGF knock-outs exhibit defects in BFCNs is not known. One possible explanation for the less severe cholinergic phenotype in NGF $(-/-)$ mice is that there is a small amount of endogenous TrkA signaling in these mice, which is ligandindependent. Alternatively, other trophic factors might signal through TrkA in the absence of the preferred ligand of TrkA, NGF. There is some precedence for this idea; NT-3 can signal through TrkA and TrkB in certain cells in vitro (Lamballe et al., 1991; Soppet et al., 1991; Squinto et al., 1991; Ip et al., 1993; Clary and Reichardt, 1994; Davies et al., 1995), albeit at a significantly higher $\mathrm{ED}_{50}$. Whether such "crosstalk" can take place in vivo remains to be determined.

trkA $(+/-)$ heterozygous mice did not differ from wild-type littermates in the appearance or size of striatal and basal forebrain cholinergic neurons at P22-P25, suggesting that the level of receptor is not the limiting factor in regulating the normal maturation of these neurons. Indeed, observations of cholinergic defects in adult NGF $(+/-)$ heterozygotes $(\mathrm{K}$. Chen and $\mathrm{H}$. Phillips, personal communication) suggest that the level of ligand is limiting.

\section{Does $\mathrm{p} 75^{\mathrm{NTR}}$ play a role in neuronal death?}

In vitro data suggest that $\mathrm{p} 75^{\mathrm{NTR}}$ can mediate apoptosis in certain cell types (Rabizadeh et al., 1993; Rabizadeh and Bredesen, 1994; Carter and Lewin, 1997). Observations of increased numbers of BFCNs in p75 NTR $(-/-)$ mice are consistent with such a role for $\mathrm{p} 75^{\mathrm{NTR}}$ (Van der Zee et al., 1996). It has been proposed that specifically those cholinergic neurons that express $p 75^{\text {NTR }}$, but not trkA, are the ones that die during postnatal development (Van der Zee et al., 1996). Our data do not support this hypothesis entirely. We observed p $75^{\text {NTR }}$ immunoreactivity in BFCNs of trkA knock-out animals through P25. However, despite the continued expression of $\mathrm{p} 75^{\mathrm{NTR}}$ in the absence of trkA during this time, most of these cells were still present at P25. Thus, many neurons that are $\mathrm{p} 75^{\mathrm{NTR}}$-positive and trkA-negative encounter NGF and do not die over a 4 week period.

In sum, our data demonstrate a critical role for TrkA in the developmental maturation of basal forebrain and striatal cholinergic neurons. TrkA signaling seems to be necessary for normal cell size and fiber maintenance, but not initial axon outgrowth. Although our data suggest that TrkA in the CNS also may be required for neuronal survival, other experiments using techniques such as tissue-specific gene targeting will be required to prove this point.

\section{REFERENCES}

Albers KM, Wright DE, Davis BM (1994) Overexpression of nerve growth factor in epidermis of transgenic mice causes hypertrophy of the peripheral nervous system. J Neurosci 14:1422-1432.

Alcantara S, Frisen J, Del Rio JA, Soriano E, Barbacid M, Silos-Santiago I (1997) TrkB signaling is required for postnatal survival of CNS neurons and protects hippocampal and motor neurons from axotomyinduced death. J Neurosci 17:3623-3633.

Alderson RF, Alterman AL, Barde YA, Lindsay RM (1990) Brainderived neurotrophic factor increases survival and differentiated functions of rat septal cholinergic neurons in culture. Neuron 5:297-306. 
Anderson KJ, Dam D, Lee S, Cotman CW (1988) Basic fibroblast growth factor prevents death of lesioned cholinergic neurons in vivo. Nature 332:360-361.

Barbacid M (1994) The Trk family of neurotrophin receptors. J Neurobiol 25:1386-1403.

Batchelor PE, Armstrong DM, Blaker SM, Gage FH (1989) Nerve growth factor receptor and choline acetyltransferase colocalization in neurons within the rat forebrain: response to fimbria-fornix transection. J Comp Neurol 284:187-204.

Burke MA, Apter JR, Wainer BH, Mufson EJ, Kordower JH (1994a) Age-related vulnerability of developing cholinergic basal forebrain neurons following excitotoxic lesions of the hippocampus. Exp Neurol 128:159-171.

Burke MA, Mobley WC, Cho J, Wiegand SJ, Lindsay RM, Mufson EJ, Kordower JH (1994b) Loss of developing cholinergic basal forebrain neurons following excitotoxic lesions of the hippocampus: rescue by neurotrophins. Exp Neurol 130:178-195.

Carter BD, Lewin GR (1997) Neurotrophins live or let die: does p75 ${ }^{\text {NTR }}$ decide? Neuron 18:187-190.

Cavalieri B (1966) Geometria degli indivisibili. Torino, Italy: Unione Tipografico.

Cavicchioli L, Flanigan TP, Vantini G, Fusco M, Polato P, Toffano G, Walsh FS, Leon A (1989) NGF amplifies expression of NGF receptor messenger RNA in forebrain cholinergic neurons of rats. Eur J Neurosci 1:258-262.

Chao MV (1992) Neurotrophin receptors: a window into neuronal differentiation. Neuron 9:583-593.

Chao MV, Bothwell MA, Ross AH, Koprowski H, Lanahan AA, Buck CR, Sehgal A (1986) Gene transfer and molecular cloning of the human NGF receptor. Science 232:518-521.

Clary DO, Reichardt LF (1994) An alternatively spliced form of the nerve growth factor receptor TrkA confers an enhanced response to neurotrophin-3. Proc Natl Acad Sci USA 91:11133-11137.

Conover JC, Erickson JT, Katz DM, Bianchi LM, Poueymirou WT, McClain J, Pan L, Helgren M, Ip NY, Boland P, Friedman B, Wiegand S, Vejsada R, Kato AC, DeChiara TM, Yancopoulos GD (1995) Neuronal deficits, not involving motor neurons, in mice lacking BDNF and/or NT4. Nature 375:235-238.

Cooper JD, Skepper JN, da Penha Berzaghi M, Lindholm D, Sofroniew MV (1996) Delayed death of septal cholinergic neurons after excitotoxic ablation of hippocampal neurons during early postnatal development in the rat. Exp Neurol 139:143-155.

Coyle JT, Price DL, DeLong MR (1983) Alzheimer's disease: a disorder of cortical cholinergic innervation. Science 219:1184-1190.

Crowley C, Spencer SD, Nishimura MC, Chen KS, Pitts-Meek S, Armanini MP, Ling LH, McMahon SB, Shelton DL, Levinson AD, Phillips HS (1994) Mice lacking nerve growth factor display perinatal loss of sensory and sympathetic neurons yet develop basal forebrain cholinergic neurons. Cell 76:1001-1011.

Davies AM, Minichiello L, Klein R (1995) Developmental changes in NT3 signaling via TrkA and TrkB in embryonic neurons. EMBO J 14:4482-4489.

Davis BM, Albers KM, Seroogy KM, Katz DM (1994) Overexpression of nerve growth factor in transgenic mice induces novel sympathetic projections to primary sensory neurons. J Comp Neurol 349:464-474.

Edwards RH, Rutter WJ, Hanahan D (1989) Directed expression of NGF to pancreatic B cells in transgenic mice leads to selective hyperinnervation of the islets. Cell 58:161-170.

Ernfors P, Lee KF, Jaenisch R (1994) Mice lacking brain-derived neurotrophic factor develop with sensory deficits. Nature 368:147-150.

Fagan AM, Zhang H, Landis S, Smeyne RJ, Silos-Santiago I, Barbacid M (1996) TrkA, but not TrkC, receptors are essential for survival of sympathetic neurons in vivo. J Neurosci 16:6208-6218.

Fagan AM, Suhr ST, Lucidi-Phillipi CA, Peterson DA, Holtzman DH, Gage FH (1997) Endogenous FGF-2 is important for cholinergic sprouting in the denervated hippocampus. J Neurosci 17:2499-2511.

Farinas I, Jones KR, Backus C, Wang X, Reichardt LF (1994) Severe sensory and sympathetic deficits in mice lacking neurotrophin-3. Nature 369:658-661.

Friedman WJ, Ibanez CF, Hallbook F, Persson H, Cain LD, Dreyfus CF, Black IB (1993) Differential actions of neurotrophins in the locus coeruleus and basal forebrain. Exp Neurol 119:72-78.

Gage FH, Tuszynski MH, Chen KS, Fagan AM, Higgins GA (1991) Nerve growth factor function in the central nervous system. In: Current topics in microbiology and immunology: neuronal growth factors (Bothwell M, ed), pp 71-93. Berlin: Springer.

Gallyas F, Wolff JR, Bottcher H, Zaborszky L (1980) A reliable and sensitive method to localize terminal degeneration and lysosomes in the central nervous system. Stain Technol 55:299-306.

Gnahn H, Hefti F, Heumann R, Schwab ME, Thoenen H (1983) NGFmediated increase of choline acetyltransferase (ChAT) in the neonatal rat forebrain: evidence for a physiological role of NGF in the brain. Dev Brain Res 9:42-52.

Gundersen HJG (1986) Stereology of arbitrary particles. A review of unbiased number and size estimators and the presentation of some new ones, in memory of William R. Thompson. J Microsc 143:3-45.

Hagg T, Vahlsing HL, Manthorpe M, Varon S (1990) Nerve growth factor infusion into the denervated adult rat hippocampal formation promotes its cholinergic reinnervation. J Neurosci 10:3087-3092.

Hagg T, Quon D, Higaki J, Varon S (1992) Ciliary neurotrophic factor prevents neuronal degeneration and promotes low affinity NGF receptor expression in the adult rat CNS. Neuron 8:145-158.

Hefti F, Hartikka J, Salvatierra A, Weiner WJ, Mash DC (1986) Localization of nerve growth factor receptors in cholinergic neurons of the human basal forebrain. Neurosci Lett 69:37-41.

Higgins GA, Koh S, Chen KS, Gage FH (1989) NGF induction of NGF receptor gene expression and cholinergic neuronal hypertrophy within the basal forebrain of the adult rat. Neuron 3:247-256.

Holtzman DM, Lowenstein DH (1995) Selective inhibition of axon outgrowth by antibodies to NGF in a model of temporal lobe epilepsy. J Neurosci 15:7062-7070.

Holtzman DM, Li Y, Parada LF, Kinsman S, Chen CK, Valletta JS, Zhou J, Long J, Mobley WC (1992) p140 ${ }^{\text {trk }}$ mRNA marks NGFresponsive forebrain neurons: evidence that trk gene expression is induced by NGF. Neuron 9:465-478.

Holtzman DM, Kilbridge J, Bredt DS, Black SM, Li Y, Clary DO, Reichardt LF, Mobley WC (1994) NOS induction by NGF in basal forebrain cholinergic neurons: evidence for regulation of brain NOS by a neurotrophin. Neurobiol Dis 1:51-60.

Holtzman DM, Kilbridge J, Li Y, Cunningham ET, Lenn NJ, Clary DO, Reichardt LF, Mobley WC (1995) TrkA expression in the CNS: evidence for the existence of several novel NGF-responsive CNS neurons. J Neurosci 15:1567-1576.

Holtzman DM, Santucci D, Kilbridge J, Chua-Couzens J, Fontana DJ, Daniels SE, Johnson RM, Chen KS, Sun Y, Carlson E, Alleva E, Epstein CJ, Mobley WC (1996) Developmental abnormalities and age-related neurodegeneration in a mouse model of Down syndrome. Proc Natl Acad Sci USA 93:13333-13338.

Ip NY, Stitt TN, Tapley P, Klein R, Glass DJ, Fandl J, Greene LA, Barbacid M, Yancopoulos GD (1993) Similarities and differences in the way neurotrophins interact with the Trk receptors in neuronal and nonneuronal cells. Neuron 10:137-149.

Johnson EM, Gorin PG (1980) Dorsal root ganglion neurons are destroyed by exposure in utero to maternal antibody to nerve growth factor. Science 210:916-918

Jones KR, Farinas I, Backus C, Reichardt LF (1994) Targeted disruption of the BDNF gene perturbs brain and sensory neuron development but not motor neuron development. Cell 76:989-999.

Kaplan DR, Hempstead BL, Martin-Zanca D, Chao MV, Parada LF (1991) The trk proto-oncogene product: a signal-transducing receptor for nerve growth factor. Science 252:554-558.

Klein R, Nanduri V, Jing SA, Lamballe F, Tapley P, Bryant S, CordonCardo C, Jones KR, Reichardt LF, Barbacid M (1991) The trkB tyrosine protein kinase is a receptor for brain-derived neurotrophic factor and neurotrophin-3. Cell 66:395-403.

Klein R, Smeyne RJ, Wurst W, Long LK, Auerback BA, Joyner AL, Barbacid M (1993) Targeted disruption of the trkB neurotrophin receptor gene results in nervous system lesion and neonatal death. Cell 75:113-122.

Klein R, Silos-Santiago I, Smeyne RJ, Lira SA, Brambilla R, Bryant S, Zhang L, Snider WD, Barbacid M (1994) Disruption of the neurotrophin-3 receptor gene trkC eliminates Ia muscle afferents and results in abnormal movements. Nature 368:249-251.

Knüsel B, Winslow JW, Rosenthal A, Burton LE, Seid DP, Nikolics K, Hefti F (1991) Promotion of central cholinergic and dopaminergic neuron differentiation by brain-derived neurotrophic factor but not neurotrophin 3. Proc Natl Acad Sci USA 88:961-965.

Koliatsos VE, Price DL, Gouras GK, Cayouette MH, Burton LE, Winslow JW (1994) Highly selective effects of nerve growth factor, brain- 
derived neurotrophic factor, and neurotrophin-3 on intact and injured basal forebrain magnocellular neurons. J Comp Neurol 343:247-262.

Lamballe F, Klein R, Barbacid M (1991) TrkC, a new member of the trk family of tyrosine protein kinases, is a receptor for neurotrophin-3. Cell 66:967-979.

Large TH, Bodary SC, Clegg DO, Weskamp G, Otten U, Reichardt LF (1986) Nerve growth factor gene expression in the developing rat brain. Science 234:352-355.

Lauterborn JC, Bizon JL, Tran TM, Gall CM (1995) NGF mRNA is expressed by GABAergic but not cholinergic neurons in rat basal forebrain. J Comp Neurol 360:454-462.

Levi-Montalcini R (1987) The nerve growth factor 35 years later. Science 237:1154-1161.

Li Y, Holtzman DM, Kromer LF, Kaplan DR, Chua-Couzens J, Clary DO, Knusel B, Mobley WC (1995) Regulation of trkA and ChAT expression in developing rat basal forebrain: evidence that both exogenous and endogenous NGF regulate differentiation of cholinergic neurons. J Neurosci 15:2888-2905.

Liu X, Ernfors P, Wu H, Jaenisch R (1995) Sensory but not motor neuron deficits in mice lacking NT4 and BDNF. Nature 375:238-241.

Longo FM, Holtzman DM, Grimes ML, Mobley WC (1992) Nerve growth factor: actions in the peripheral and central nervous systems. In: Neurotrophic factors (Fallon J, Loughlin S, eds), pp 209-256. New York: Academic.

Lu B, Buck CR, Dreyfus CF, Black IB (1989) Expression of NGF and NGF receptor mRNAs in the developing brain: evidence for local delivery and action of NGF. Exp Neurol 104:191-199.

Martinez HJ, Dreyfus CF, Jonakait GM, Black IB (1985) Nerve growth factor promotes cholinergic development in brain striatal cultures. Proc Natl Acad Sci USA 82:7777-7781.

Meakin SO, Shooter EM (1991) Tyrosine kinase activity coupled to the high-affinity nerve growth factor-receptor complex. Proc Natl Acad Sci USA 88:5862-5866.

Milner TA, Loy R, Amaral DG (1983) An anatomical study of the development of the septohippocampal projection in the rat. Dev Brain Res 8:343-371.

Minichiello L, Klein R (1996) TrkB and TrkC neurotrophin receptors cooperate in promoting survival of hippocampal and cerebellar granule neurons. Genes Dev 10:2849-2858.

Mobley WC, Rutkowski JL, Tennekoon SJ, Buchanan K, Johnston MV (1985) Choline acetyltransferase in striatum of neonatal rats increased by nerve growth factor. Science 229:284-287.

Mobley WC, Rutkowski JL, Tennekoon GI, Gemski J, Buchanan K, Johnston MV (1986) Nerve growth factor increases choline acetyltransferase activity in developing basal forebrain neurons. Mol Brain Res 387:53-62.

Mobley WC, Woo JE, Edwards RH, Riopelle RJ, Longo FM, Weskamp G, Otten U, Valletta JS, Johnston MV (1989) Developmental regulation of nerve growth factor and its receptor in the rat caudate-putamen. Neuron 3:655-664.

Olton D, Markowska A, Voytoko ML, Givens B, Gormon L, Wenk G (1991) Basal forebrain cholinergic system: a functional analysis. Adv Exp Med Biol 295:353-372.

Otto D, Frotscher M, Unsicker K (1989) Basic fibroblast growth factor and nerve growth factor administered in gelfoam rescue medial septal neurons after fimbria fornix transection. J Neurosci Res 22:83-91.

Rabizadeh S, Bredesen DE (1994) Is p75 NGFR involved in developmental neural cell death? Dev Neurosci 16:207-211.

Rabizadeh S, Oh J, Zhong L, Yang J, Bitler CM, Butcher LL, Bredesen DE (1993) Induction of apoptosis by the low-affinity NGF receptor. Science 261:345-358.

Radeke MJ, Misko TP, Hsu C, Herzenberg LA, Shooter EM (1987) Gene transfer and molecular cloning of the rat nerve growth factor receptor. Nature 325:593-597.
Richardson RT, DeLong MR (1988) A reappraisal of the functions of the nucleus basalis of Meynert. Trends Neurosci 11:264-267.

Rodriguez-Tebar A, Dechant G, Barde YA (1990) Binding of brainderived neurotropic factor to the nerve growth factor receptor. Neuron 4:487-492.

Rodriguez-Tebar A, Dechant G, Gotz R, Barde YA (1992) Binding of neurotrophin-3 to its neuronal receptors and interactions with nerve growth factor and brain-derived neurotrophic factor. EMBO J 11:917-922.

Saffran BN, Woo JE, Mobley WC, Crutcher KA (1989) Intraventricular NGF infusion in the mature rat brain enhances sympathetic innervation of cerebrovascular targets but fails to elicit sympathetic ingrowth. Brain Res 492:245-254.

Schwarz M, Ikonomidou C, Klockgether T, Turski L, Ellenbroek B, Sontag KH (1986) The role of striatal cholinergic mechanisms for the development of limb rigidity: an electromyographic study in rats. Brain Res 373:378-381.

Silos-Santiago I, Molliver DC, Ozaki S, Smeyne RJ, Fagan AM, Barbacid M, Snider WD (1995) Non-TrkA-expressing small DRG neurons are lost in trkA deficient mice. J Neurosci 15:5929-5942.

Smeyne RJ, Klein R, Schnapp A, Long LK, Bryant S, Lewin A, Lira SA, Barbacid M (1994) Severe sensory and sympathetic neuropathies in mice carrying a disrupted Trk/NGF receptor gene. Nature 368:246-249.

Snider WD (1994) Functions of the neurotrophins during development: what the knockouts are teaching us. Cell 77:627-638.

Sobreviela T, Clary DO, Reichardt LF, Brandabur MM, Kordower JH, Mufson EJ (1994) TrkA-immunoreactive profiles in the central nervous system: colocalization with neurons containing $\mathrm{p} 75$ nerve growth factor receptor, choline acetyltransferase, and serotonin. J Comp Neurol 350:587-611.

Soppet D, Escandon E, Maragos J, Middlemas DS, Reid SW, Blair J, Burton LE, Stanton BR, Kaplan DR, Hunter T, Nikolics K, Parada LF (1991) The neurotrophic factors brain-derived neurotrophic factors and neurotrophin-3 are ligands for the trkB tyrosine kinase receptor. Cell 65:895-903.

Squinto SP, Stitt TN, Aldrich TH, Davis S, Bianco SM, Radziejewski C, Glass DJ, Masiakowski P, Furth ME, Valenzuela DM, Distefano PS, Yancopoulos GD (1991) trkB encodes a functional receptor for brainderived neurotrophic factor and neurotrophin-3 but not nerve growth factor. Cell 65:885-893.

Steininger TL, Wainer BH, Klein R, Barbacid M, Palfrey HC (1993) High-affinity nerve growth factor receptor (Trk) immunoreactivity is localized in cholinergic neurons of the basal forebrain and striatum in the adult rat brain. Brain Res 612:330-335.

Thoenen H (1991) The changing scene of neurotrophic factors. Trends Neurosci 14:165-170.

Van der Zee CEEM, Ross GM, Riopelle RJ, Hagg T (1996) Survival of cholinergic forebrain neurons in developing p75 ${ }^{\mathrm{NGFR}_{-}}$-deficient mice. Science 274:1729-1732.

Vantini G, Schavo N, DiMartino A, Polato P, Triban C, Callegaro L, Toffano G, Leon A (1989) Evidence for a physiological role for nerve growth factor in the central nervous system of neonatal rats. Neuron 3:267-273.

Weskamp G, Reichardt LF (1991) Evidence that biological activity of NGF is mediated through a novel subclass of high-affinity receptors. Neuron 6:649-663.

West MJ (1993) New stereological methods for counting neurons. Neurobiol Aging 14:275-285.

Whittemore SR, Ebendal T, Larkfors L, Olson L, Seiger A, Stromberg I, Persson H (1986) Developmental and regional expression of betanerve growth factor messenger RNA and protein in the rat central nervous system. Proc Natl Acad Sci USA 83:817-821. 